\title{
Belgeo
}

Revue belge de géographie

\section{Engendering Spanish geography}

Sexuer la géographie espagnole

Fabia Diaz Cortés, Maria Dolors Garcia Ramon and Anna Ortiz

\section{(2) OpenEdition}

Journals

Electronic version

URL: http://journals.openedition.org/belgeo/11207

DOI: 10.4000/belgeo. 11207

ISSN: 2294-9135

\section{Publisher:}

National Committee of Geography of Belgium, Société Royale Belge de Géographie

\section{Printed version}

Date of publication: 30 September 2007

Number of pages: 323-334

ISSN: 1377-2368

\section{Electronic reference}

Fabia Diaz Cortés, Maria Dolors Garcia Ramon and Anna Ortiz, « Engendering Spanish geography », Belgeo [Online], 3 | 2007, Online since 11 December 2013, connection on 22 May 2020. URL : http:// journals.openedition.org/belgeo/11207 ; DOI : https://doi.org/10.4000/belgeo.11207

This text was automatically generated on 22 May 2020 .

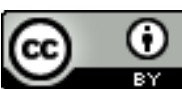

Belgeo est mis à disposition selon les termes de la licence Creative Commons Attribution 4.0 International. 


\title{
Engendering Spanish geography
}

\author{
Sexuer la géographie espagnole
}

Fabia Diaz Cortés, Maria Dolors Garcia Ramon and Anna Ortiz

1 For over two decades, gender studies have been advanced in Spanish geography constituting a subfield of social and cultural geography. On the one hand, they have incorporated the international perspectives that understand gender as a construction challenging the artificial boundaries between the social, the cultural and the economic which understands that culture, as a social construction, is a basic instrument of social change. On the other hand, there have been distinctive features of Spanish work on gender, consonant with national traditions. While it originated as an outgrowth of research by geographers interested in radical and Marxist perspectives in the discipline, even as it drew early inspiration from the British and American work, it has had more of a social orientation. Additionally, although it presented a rupture with earlier Spanish work, it has sustained the tradition of being more applied than theoretical.

2 The rupture has been expressed in terms of content, but also through its methodological innovations. In this respect, it contrasts with the practices in many Spanish universities where geographers have continued to work within the framework of traditional regional geography, although updated through the introduction of new technologies, in particular GIS, and have brought in applied approaches to environmental studies. By contrast, gender studies have made a marked break with traditional approaches, not only in their conceptual orientation but in introducing qualitative methodologies that were initially resisted but are today beginning to be accepted.

3 Qualitative methods have their origins in phenomenological theory which concerns itself with subjective experiences and the intent of defining and interpreting everyday lives. This methodology, drawing for example, on in-depth interviews, life histories, and participant observation (García Ballesteros, 1998), was exemplified early in Spanish work by Aurora García Ballesteros (1986). Although some early gender research on rural women drew on census data and quantitative methods (Solsona, 1989), it clearly revealed the limitations of such data for representing women's work and prompted a 
turn to qualitative methods, especially of in-depth interviewing (Sabaté et al.,1995). Many of the PhD theses that have dealt with gender have used these methodologies, some of them quite early in time (Baylina, 1997, 2004a ; Blanco, 2005 ; Caballé, 1997, 1998 ; Cánoves, 1990 ; Morales, 2002 ; Ortiz, 2004 ; Prats, 1997, 1998). All these works and the following publications that we will cite have contributed to the growing recognition of qualitative methods as legitimate by Spanish geographers, a recognition that is becoming acknowledged as orthodox in Anglophone geography, not constantly in need of justification (Crang, 2002).

In this paper, in the first section we will deal with the institutional aspects linked to gender and power within the discipline in Spain; then, in the second one, we will deal with three topics that have been relevant in Spanish gender geography : the study of rural spaces, research on urban spaces and studies in postcolonial geography.

\section{Gender and power in Spanish academic geography}

5 In the 1980s, several studies were carried out which examined the presence and status of women in geography as well as their scientific production as indicated by publications in specialised journals (García Ballesteros, 1982 ; Sabaté, 1984 ; Castañer et al., 1985 ; Garcia-Ramon et al., 1988). Numerically speaking, women's presence was relatively high compared to other more established disciplines and also to women's representation in academic geography in a number of other countries, due in part to the fact that university degree programmes in geography were not created in Spain until the late 1970s and that they were heavily teaching-oriented. Women's status, power and scientific production in the discipline, however, were rather low. Recently, this topic has been re-examined and it has been found that although the Law on University Reform (LRU) has contributed to raising female geographers' academic status, there are signs that the discipline is becoming more male-dominated, in terms of both professors and students (Garcia-Ramon et al., 2004). This most likely reflects the fact that the discipline is becoming more and more professional and technical, and it is widely understood that women are less inclined to choose technical and scientific university majors and professions. It would be important to examine this avenue of thinking in more depth in the near future in order to discern more accurately the mechanisms involved and to be able to take measures to create a friendly, attractive environment for women in academic and professional geography.

6 It is also true that attention to gender studies within geography and of women geographers is unevenly represented in Spanish universities (Pujol, 2004). Two wellestablished research groups, one at Complutense University of Madrid, the other at the Autonomous University of Barcelona, have been the impetus and unifying force in gender studies within the discipline. The gender research in these programs has been supported by an array of grants from national and regional governmental agencies, including those dedicated to work on women ${ }^{1}$ and by some international funds ${ }^{2}$. Geographers in these two institutions have formed a supportive group for each other and have also built strong and steady relations with individual researchers interested in gender studies at five additional universities (Girona, Santiago de Compostela, Valencia, Sevilla and La Coruña). Nevertheless, only two courses on gender as such are offered at the undergraduate level, though the degree in geography is given in 26 departments. Gender-aware teachers have introduced the topic into other regularly 
taught courses, however, though the syllabi only occasionally make explicit reference to gender. At the graduate level, the case differs somewhat, courses on gender having been taught in at least seven universities, often in interdisciplinary programs. During the last 14 years, 13 doctoral degrees and at least twice as many master's degrees focusing on gender have been awarded, a good number of them at the Autonomous University of Barcelona. Additionally, publication of a textbook on gender (Sabaté et al., 1995) has provided a resource for teaching that has been used at the university level and also in some schools.

7 The Autonomous University of Barcelona offers an interesting example of the strategies that have been adopted to advance gender studies. The Group on Gender Studies in Geography was created in 1987 and formally recognized by the administration of the university in 1995. From its initiation, this Group was directed by Maria Dolors Garcia- Ramon, an established full professor. This situation contrasts with that in some other countries where those attempting to introduce gender research and teaching are junior scholars. The Barcelona group consciously adopted strategies that would advance and consolidate its position. These included: incorporating multiple members of the department, including young researchers and graduate students; seeking external research funds (regional, national and international); developing competitive scholarly records by publishing in refereed journals, nationally and internationally; teaching specialised courses in gender; establishing a modest documentation centre on themes related to its research ; presenting at international meetings; forming a supportive local informal network; and establishing relations with geographers outside Spain, by going abroad themselves and inviting foreign geographers into the department.

\section{Relevant research topics in gender geography in Spain}

8 We will not aim to be exhaustive in reviewing the work carried out since the 1980's as some detailed state of the art articles on the topic have recently been published (Garcia-Ramon, 2005 ; Prats, 2006). But we will discuss the research carried out in specific topics that seem to have been predominant in Spanish gender geography.

\section{Gender and processes of rural and regional restructuring}

For many years, this avenue of research has been important, in keeping with the rural tradition of Spanish geography. Studies have mainly been undertaken by the gender groups which emerged at the end of the 1980s at the Complutense University of Madrid and the Autonomous University of Barcelona. Two main lines of research were developed, both examining women's work in the rural environment: women's contribution to work on family-run farms and the role of women in the economic diversification of rural areas. Within the former, a series of studies on women's contributions to family-run farms in different regions is worth mentioning. These demonstrated that women's contributions to work are quite important when all the real work (both productive and reproductive) is taken into account. Women's work on farms is discontinuous, irregular and highly diversified, so that many of the productive tasks are difficult to separate from household work. It is therefore difficult to take into account in agricultural statistics which thus poorly reflect women's work. This research 
showed that the survival of family-run farms in Spain hinges on women's participation, both in areas where agricultural activities are more marginal and in areas where agriculture is intense and competitive (Garcia-Ramon et al., 1995; 1996). It has also contributed to theoretical debates on the division between productive and reproductive labour, making clear that any attempt to explain women's work in this context had to take into consideration the patriarchal control of the work process and the ownership of the means of production (Nieto, 2004). In sum, these studies offered significant ideas on the cultural construction of masculinity and femininity in the rural contexts of different Spanish autonomous communities. We should also note that the comparative approach adopted in these rural studies, involving research at multiple sites, has been one of the hallmarks of Spanish geographic work on gender. Since geographers are especially interested in differences between distinct spaces (GarciaRamon et al., 1993), this approach also enhanced the identification of the work as geography, both within and beyond the discipline.

Because the agricultural sector in Spain has been losing ground in the past fifteen years, it was crucial to inquire what has been and is the role of women in the process of rural restructuring, since understanding this is necessary for designing rural policies. One of the earliest studies centred on the processes of economic diversification, especially on the location of light industries; this research demonstrated that the advantages provided by women, including lower-cost labour and a lower tendency towards conflict than identified with men's labour, were very important factors when attracting industry (Sabaté, 1993). Later, other types of activities, some of them innovative, such as rural tourism (Cánoves et al., 1997) and telecommuting (Blanco, 2005) and some more traditional, such as jobs in agro-industries or at home (GarciaRamon et al., 2000 ; Prados, 1998), were examined in different Spanish autonomous communities. In particular, informal industrial at-home work has been studied in various autonomous communities (Baylina et al., 1998, 2004b). The work carried out by women in such settings is characterised by being informal, labour intensive, and barely remunerated. Nevertheless, it cannot simply be placed alongside marginality or represent the survival of forms of work bound for extinction. In many cases the practice of homework puts roots into new soil, constituting a show of resistance against the competitive pressures of the market. In this context, women are seen as the best candidates for working in the home because they are identified as being more dependent that men on local employment opportunities and socially perceived as more adaptable and docile. In this sense they constitute a social and human capital that is crucial to rural and local development (Pallarès et al., 2003; Baylina 2004b). As researchers committed to equal opportunity, we must not marginalise their role (even if it is of this type), rather we must make these women more visible and condemn the specific circumstances in which they must do their jobs and insist on the need for a substantial change in gender roles and relations (Sabaté, 2002).

11 Recently, two topics have been examined which fall within the theoretical framework of inter-gender relations and the environment. First, work has been done in the field of ecological agriculture, namely on women's participation in the different productive phases of biological foodstuffs in an attempt to answer the question of whether men and women have a different relationship with this production (López, 2000). The results demonstrate that women producers are in a position to fully profit from their advantages and play a leading role in an emerging sector in rural areas. A second area 
of research has studied the roles of rural women in natural resources management and sustainable development, especially in regions with protected areas (Canosa et al., 2000). Emphasis is placed on the consequences for women of current policies on rural development and nature conservation implemented by various public administrations, both in Spain and in the European Union (this is being examined mainly via the Leader programmes that are part of initiatives to revitalise lagging regions). It is important to continue work on both lines of inquiry in order to have at our disposal the elements needed to design rural development policies that take into account these recent processes which are so closely linked to the environment.

\section{Gender, time, work and urban spaces}

12 The earliest urban studies centred on female mobility, especially in terms of commuting to work, a research topic with deep roots in the field of geography (Díaz et al., 1989). The study of women's timetables in the city was undertaken as early as the 1990s, inspired by the debates coming from the Italian left wing (Prats et al., 1995, 2004). Given the challenge of the massive influx of women into the labour force and the rigidity of lifestyles and timetables in cities, especially in southern Europe, an attempt was made to consider how women managed their time and to study the timetables of businesses and services and their appropriateness in light of the demand, as well as to provide recommendations aimed at fostering greater freedom and equality in the use of time. For the city of Barcelona, it was shown that there was fierce competition in finding time for both productive and reproductive work, for leisure activities and at night, but the time spent on productive work clearly emerged as the most important and the most rigid, around which all the other times were organised, thus creating a feeling of anxiety and "time famine". Based on the recommendations generated, the Barcelona Town Hall initiated a series of policies that proposed, on an experimental basis, a series of changes in the timetables for services, facilities and shops in one Barcelona neighbourhood. In a subsequent phase of action, "Time Banks" have been organised in various neighbourhoods in order to exchange time benefits. The issue of making work schedules more flexible was also a central point in the study of women's work in the retail sector in metropolitan areas; however, in this case, it is a type of flexibility that benefits not women but only the companies (Ortiz et al., 2000).

The role of women in defending the urban environment has also been approached in studies of female citizens' movements or women-led movements (Brú, 1995, 1996). This work has involved comparative regional research on mobilisations protesting environmental risks (related to the presence of industrial waste) in municipalities in various autonomous communities. It has revealed that women's views of the environment were quite different from usually accepted rigid, androcentric views. It also suggested the need to define the concept of environment more broadly in order to encompass a conception that is much more closely tied to the consequences of environmental impacts on daily life (on health, on our surroundings, on our families' well-being, and so forth).

14 Another recent avenue of research involves analysing a series of urban planning actions undertaken in the past fifteen years in Catalan cities of varying sizes (Baylina et al., 2004 ; Cucurella et al., 2006 ; Díaz-Cortés, 2007 ; Garcia-Ramon et al., 2004 ; Ortiz et al., 2002 ; Serra, 2003). Women have been absent from urban planning, not only as users of 
public spaces, but also as urban planners. The research examined a series of actions aimed at rehabilitating urban spaces which had included among their objectives the fight against socio-spatial exclusion. These actions were examined first by analysing the concepts and strategies underlying these actions, and second by looking at the nature and degree of the real impact of these measures on social and gender exclusion. In addition to comparing different sites, an important focus in these studies has been the integration of social characteristics such as ethnicity and age as they intersect with gender. The research carried out to date has focused on four types of measures : reassessing public spaces, public transport, housing, and promoting the functional and social complexity of urban spaces. The potential of public spaces as an integrating force has been shown, as has the fact that their design is a crucial element to foster the presence of women in an effort to overcome their traditional social and spatial isolation and, in short, to encourage the processes of emancipation. In considering differences within groups, as well as between males and females, these studies question the hegemony of the knowledge of professional planners that assume "absolute" values in physical design and do not take into account cultural diversity, relations of power within communities, or how the perceptions and identities of the users might differ from their own. It would be interesting to delve more deeply into this line of inquiry because the planning of public spaces from the perspectives of human diversity could be an important step toward creating socially and culturally meaningful spaces, and ultimately toward achieving more inclusive participation in city life.

One particular line of this research on uses of public spaces has focused on boys and girls, seeing the spaces as educational sites and learning in everyday life. One of these (Baylina et al., 2005, 2006) situates the research in mid-sized Catalan cities. It demonstrates without doubt that play spaces are basic for children's development and are sites in which they observe, question, and contest traditional gender roles.This observation is especially pertinent in Spanish cities where public space is so much a part of everyday life and where gender norms have been so little transgressed. The research concludes that not only planners and architects should be involved in design, but also that specialists such as child psychologists, teachers, and children themselves should be incorporated into initiatives by municipal governments.

Most recently, the interest in difference has turned to aspects of sexuality within cities. Recent studies by García Escalona (2000) and Santos (2002) highlight connections between sexuality and processes of gentrification and also how the appropriation of urban spaces forms part of an empowerment strategy for these groups.

\section{Reinterpreting colonial discourses : travellers, cultural borders and gender identity}

17 Colonialism, and its ideological justifications, frequently exemplified in travel writings, became a crucial component of a nascent geography at the end of the $19^{\text {th }}$ century. If it is true that its study has been incorporated into the historiography of the discipline in recent years, it is also the case that the contributions of travel writers and explorers have been significantly undervalued. But recent postcolonial and feminist studies aim to evaluate the contribution of travellers - especially of women - to colonial discourse since this literature offers a less monolithic vision of this discourse. In fact, some of the women travellers transform their own identities through colonial contact, seeking to 
supersede cultural boundaries and establish a non-hierarchical contact with women living in overseas environments. The ambivalence between the world of the coloniser and the colonised is more frequently observed in writings by women travellers than in the writings of men who were serving colonial administrators (Garcia-Ramon et al., 1998 ; Albet et al., 1998, 1999 ; Garcia-Ramon, 2003, 2007).

Currently, research is being carried out on the role of geography in colonialism in the Spanish Protectorate of Morocco (Nogué et al., 1999 ; Garcia-Ramon et al., 2007) and on the role of Spanish travellers in the construction of colonial discourse in Africa. This research has revealed quite a few women and men travellers from mid $19^{\text {th }}$ to mid $20^{\text {th }}$ century. The initial hypothesis is that the vision that the Catalan traveller offers of the Africa colonies, and especially of the Spanish possessions, may differ from that of Spanish travellers who tended to be in the military or in the diplomatic or administrative service, and therefore more likely to represent the "official" colonial version of the metropolis. Catalan women and men, by comparison, not only belong to none of these categories but also offer an image more "distant" at times more critical and frequently also more oriented to leisure or commerce. One important focus of this research has also been the analysis of the images of women that appear in men's travel narratives (Cerarols, 2007), images that confirm the orientalist gaze of most of the travellers. Finally, we should mention that new topics are emerging that adopt postcolonial and postmodern perspectives. Gender identity has been one of the main foci in postcolonial interpretation of extra-communitarian women migrants to Spain (Pedone, 2006) while Brú (2004) has adopted a postmodern approach to research on the theme of the gendered body in relation to nature and landscape.

\section{Concluding Thoughts}

We consider that the focus on gender has enriched the discipline of geography in Spain in multiple ways, especially by bringing to light certain aspects of society that the pragmatic tendency of applied geography so prevalent in our country tends to neglect. The use of powerful and presumably "neutral" techniques and methods of analysis in effect neglects fundamental dimensions of social reality, among them the gender relations that permeate and affect both aspects of daily life, especially the use of space, the allocation of time and the very concept of work.

Additionally, we believe that while feminist research in other disciplines has come to use notions such as context, location and situation, yet this is almost always in reference to a cultural space. To the field of geography, sensitivity to context means observing facts and objects on the ground, in specific places and at specific times. The geographic tradition has always been fascinated by difference, that is, differences in space and territory. We recognise that people learn culture in different ways in different regions and that also includes specific social constructions of gender roles. We must gain insight into how the economic environment, but also the cultural, social and natural ones play a decisive role in constructing gender roles and relations. Thus the empiricism and attention to detail that characterise a large part of geographic research compared to other social sciences, and which have frequently been viewed as a disadvantage, might, in fact, be a useful instrument for helping to contextualise the processes being studied. The geography-based approach provides gender studies with a 
dimension that should not be ignored: the systematic search for regional differences and specificity in the relations.

\section{BIBLIOGRAPHY}

ALBET A. \& GARCIA-RAMON M.D. (1998), “Los relatos de mujeres viajeras ¿una mirada crítica sobre el colonialismo ?”, Finisterra. Revista Portuguesa de Geografia, 33, 65, pp. 99-108.

ALBET A. \& GARCIA-RAMON M.D. (1999), "Reinterpretando el discurso colonial y la historia de la geografía en una perspectiva de género", in NOGUÉ J. \& VILANOVA J. L. (eds.), España en Marruecos (1912-1956), Discursos geográficos e intervención territorial, Lleida, Milenio, pp. 55-71.

BAYLINA M. (1997), “Metodología cualitativa y estudios de geografía y género”, Documents d'Anàlisi Geogràfica, 30, pp. 123-138.

BAYLINA M. (2004a), “Metodología para el estudio de las mujeres y la sociedad rural”, Estudios Geográficos, LXV, 254, pp. 5-28

BAYLINA M. (2004b), “Invisible work and exclusionary space : too many challenges for homeworkers ?", Hagar : Studies in Culture, Polity and Identity, 5, 1, pp. 53-67.

BAYLINA M. \& GARCIA-RAMON M.D. (1998), "Homeworking in rural Spain : a gender approach", European Urban and Regional Studies, 5, 1, pp. 55-64.

BAYLINA M. \& GARCIA-RAMON M. D. (2004), "Rural gender studies in Spain between 1975 and the present", in GOVERDE H. et al. (eds.) Power and Gender in European Rural Development, Aldershot, Ashgate, pp. 160-170.

BAYLINA M., PRATS M. \& ORTIZ A. (2005), “Espacios de juego como escenarios educativos urbanos", Ciudades, 67, pp. 20-25.

BAYLINA M., ORTIZ A. \& PRATS M. (2006), “Children in playgrounds in Mediterranean Cities”, Children's Geographies, 4, pp. 173-83.

BLANCO A. (2005), Teletrabajo, género y territorio : una comparación entre Cataluña, Ardèche y Quebec, Tesis de doctorado, Universitat Autònoma de Barcelona.

BRÚ J. (1995), “El medi está androcentrat. Qui el desandrocentritzarà ? Experiència femenina, coneixement ecològic i canvi cultural", Documents d'Anàlisi Geogràfica, 26, pp. 271-276.

BRÚ J. (1996), “Spanish women against industrial waste : a gender perspective on environmental grassroots movements", in ROCHELEAU D., THOMAS SLAYTER, B \& WANGARI E. (eds.) Feminist Political Ecology, London, Routledge, pp. 105-124.

BRÚ J. (2004) “Entre el cos i l'ànima : dona, natura i els paisatges de la captivitat”, Els paisatges de la postmodernitat. II Seminari Internacional sobre Paisatge, Olot, 21-23 octubre de 2004 [http// www.catpaisatge.net/cat/documentacio_seminari2004.php].

CABALLÉ A. (1997), “Aproximación al marco teórico y metodológico en la investigación de geografía del género", Cuadernos Geográficos, 27, pp. 7-27. 
CABALLÉ A. (1998), Gènere, agroturisme i context regional a l'Estat Espanyol, Tesis de doctorado, Universitat Autònoma de Barcelona.

CANOSA E., LOPEZ N., MARTIN M. A., MARTINEZ E., MARTINEZ M. L., RODRIGUEZ I. \& SAEZ E. (2000), La mujer y la conservación de la naturaleza en España : su papel en la gestión de los recursos naturales y en el desarrollo rural sostenible, Madrid, Instituto de la Mujer.

CÁNOVES G. (1990), Treball invisible, explotació agrària familiar i aportació femenina : el cas de Girona, Tesis de doctorado, Universitat Autònoma de Barcelona.

CÁNOVES G. \& VILLARINO M. (1997), "El turismo rural en Cataluña y Galicia, una alternativa o complemento a la explotación familiar : Las mujeres sus nuevas protagonistas”, in VALENZUELA M. (ed.), Los turismos de interior. El retorno de la tradición viajera, Madrid, Universidad Autónoma de Madrid, pp. 353-368.

CASTAÑER M. \& CENTELLES N. (1985), “La mujer y la geografía universitaria española”, Documents d'Anàlisi Geogràfica , 14, pp. 73-88.

CERAROLS R. (2007, forthcoming), "El viatge 'en masculí' i la dona en els relats de viatge al Marroc colonial”, in GARCIA-RAMON M.D., NOGUÉ J. \& ZUSMAN P. (eds.), Una mirada a l'Àfrica. Viatgers $i$ viatgeres dels segles XIX i XX (1859-1936), Lleida, Pagés.

CRANG M. (2002), "Qualitative methods : the new orthodoxy ?", Progress in Human Geography, 26, 5, pp. 647-655.

CUCURELLA A., GARCIA-RAMON M.D. \& BAYLINA M. (2006), “Gender, age, and design in a new public space in a Mediterranean town : The Parc dels Colors in Mollet del Vallés (Barcelona)", European Spatial Research Policy, 13, 2, pp. 181-194.

DÍAZ-CORTÉS F. (2007, forthcoming), “Dones i espais públics a barris populars : el cas de Ca n'Anglada de Terrassa", Treballs de la Societat Catalana de Geografia.

DÍAZ M. A. \& RODRÍGUEZ J. (1989), "Spatial variations of the female and male labour force participation in the Madrid Metropolitan Area”, Espaces, Populations et Societés, 1, pp. 43-52.

GARCÍA BALLESTEROS A. (1982), "El papel de la mujer en el desarrollo de la geografía”, in DURÁN M.A. (ed.), Liberación y utopía, Madrid, Akal, pp. 119-141.

GARCÍA BALLESTEROS A. (1986), "Espacio masculino, espacio femenino ? Notas para una aproximación geográfica al estudio del uso del espacio en la vida cotidiana”, in GARCíA BALLESTERos A. (ed.), El Uso del Espacio Cotidiano, Madrid, Universidad Autónoma de Madrid, pp. 13-27.

GARCÍA BALLESTEROS A. (1998), "Métodos y técnicas cualitativas de investigación en geografia social”, in GARCÍA BALLESTEROS A. (coord.), Métodos y técnicas cualitativas en geografía social, Barcelona, Oikos-Tau, pp. 13-26.

GARCÍA ESCALONA E. (2000), “'Del armario al barrio' : aproximación a un nuevo espacio urbano”, Anales de Geografía de la Universidad Complutense, 20, pp. 437-449.

GARCIA-RAMON M.D. (2003), “Gender and the colonial encounter : European women's travel narratives from the Arab world", Environmental and Planning D : Society and Space, 21, pp. 653-672.

GARCIA-RAMON M.D. (2005), "Respondiendo a un desafío pendiente en geografía : el enfoque de género visto desde España”, Geographicalia, 48, pp. 55-75.

GARCIA-RAMON M.D. (2007), Exploració, geografia i estudis postcolonials. Una mirada de gènere sobre les narratives de viatge (Gertrude Bell, 1868-1929), Barcelona, Institut d'Estudis Catalans. 
GARCIA-RAMON M.D., CASTAÑER M. \& CENTELLES N. (1988), “Women and Geography in Spanish Universities", Professional Geographer, 40, 3, pp. 307-315.

GARCIA-RAMON M.D., VILLARINO M., BAYLINA M. \& CÁNOVES G. (1993), “Farm women, gender relations and household strategies in the coast of Galicia", Geoforum, 24, 1, pp. 5-17.

GARCIA-RAMON M.D., CRUZ J., SALAMAÑA I. \& VILLARINO M. (1995), Mujer y agricultura en España. Género, trabajo y contexto regional, Barcelona, Oikos-Tau.

GARCIA-RAMON M.D. \& CRUZ J. (1996), “Regional welfare policies and women's agricultural labour in Southern Spain”, in GARCIA RAMON M.D. et al. (eds.), Women of the European Union. The politics of work and daily life, London, Routledge, pp. 247-262.

GARCIA-RAMON M.D., ALBET A., NOGUÉ J. \& RIUDOR Ll. (1998), "Voices from the margins : gendered images of 'otherness' in colonial Morocco", Gender, Place and Culture, 5 (3), pp. 229-240.

GARCIA-RAMON M.D. \& BAYLINA M. (eds.) (2000), El nuevo papel de las mujeres en el desarrollo rural, Barcelona, Oikos -Tau.

GARCIA-RAMON M.D., NOGUÉ J. \& ZUSMAN P. (2007, forthcoming), Una mirada a l'Àfrica. Viatgers i viatgeres dels segles XIX i XX (1859-1936), Lleida, Pagés.

GARCIA-RAMON M.D., ORTIZ A. \& PRATS M. (2004), "Urban planning, gender and the use of public space in a peripheral neighbourhood of Barcelona”, Cities, 21, 3, pp. 215-223.

GARCIA-RAMON M.D. \& PUJOL H. (2004), "La presencia de mujeres en la geografía académica : ¿Hacia una masculinización de la disciplina ?”, Cuadernos de Geografía, 75, pp. 91-101.

LÓPEZ R. (2000), "La agricultura ecológica como una alternativa también para las mujeres”, Actas del X Coloquio de Geografía Rural en España, Lleida, Universidad de Lleida, pp. 490-498.

MORALES S. (2002), Industria agroalimentaria, género y desarrollo rural. Un análisis comparativo desde la geografía, Tesis de doctorado, Universitat Autònoma de Barcelona.

NIETO C. (2004), Las empresarias rurales malagueñas. La respuesta de las mujeres al mercado laboral, Málaga, Publicaciones de la Universidad de Málaga.

NOGUÉ J. \& VILLANUEVA J.L. (eds.) (1999), España en Marruecos (1912-1956) : Discursos geográficos e intervención territorial, Lleida, Milenio.

ORTIZ A. (2004), Género, espacios públicos y construcción del sentido de pertenencia en Barcelona (los barrios de Prosperitat, el Verdum y el Raval), Tesis de doctorado, Universitat Autònoma de Barcelona.

ORTIZ A., ALBET A., GARCIA-RAMON M.D. \& PRATS M. (2002), Urban planning, gender and social integration in Barcelona, Volkswagen-Stiftung, University of Hanover.

ORTIZ A. \& GARCIA-RAMON M.D. (2000), "The fixed term contract, the Spanish route to flexibility? Women in the retail sector in the Barcelona region", Economic and Industrial Democracy : an International Journal, 21, 3, pp. 311-333.

PALLARÈS M., PALLARÈS M. \& TULLA A. (2003), Capital social i treball de les dones als Pirineus : el cas de l'Alt Urgell, Barcelona, Institut Català de la Dona.

PEDONE C. (2006), De l'Equador a Catalunya : el paper de la familia $i$ les xarxes migratòries, Barcelona, Mediterrània.

PRADOS M. J. (1998), “Trabajadoras de segunda clase. Mujer y empleo en el sector agroalimentario andaluz", Trabajo, 4, pp. 171-186. 
PRATS M. (1997), Temps i vida quotidiana de les dones de Barcelona, Tesis de doctorado, Universitat Autònoma de Barcelona.

PRATS M. (1998), “Geografia feminista i metodologia : reflexió sobre un procés d'aprenentatge parallel”, Cuadernos de Geografía, 64, pp. 313-323.

PRATS M. (2006), “Sexo, género y lugar” in NOGUE J. \& ROMERO J., Las Otras Geografías, València, Tirant lo Blanch, pp. 493-510.

PRATS M., GARCIA-RAMON M. D. \& CANOVES G. (1995), La mujeres y el uso del tiempo, Madrid, Ministerio de Asuntos Sociales, Instituto de la Mujer.

PRATS M. \& GARCIA-RAMON M. D. (2004), "Emploi du temps et vie quotidienne des femmes adultes à Barcelone”, Espace, population, sociétés, 1, pp. 71-79.

PUJOL H. (2004), "La presència de les dones en la geografia acadèmica : un estat de la qüestió al tombant del segle", Treballs de la Societat Catalana de Geografia, 57, pp. 221-236.

SABATÉ A. (1984), "La mujer en la investigación geográfica”, Anales de Geografía de la Universidad Complutense, 4, pp. 275-282.

SABATÉ A. (1993), "Industria rural en Toledo : la incorporación de las mujeres al mercado de trabajo”, Anales de Geografía de la Universidad Complutense, 12, pp. 277-288.

SABATÉ A. (2002), "Rural development is getting female : old and new alternatives for women in rural areas in Spain”, Antipode, 34, 5, pp. 1004-1006.

SABATÉ MARTÍNEZ A., RODRÍGUEZ MOYA J. M. \& DÍAZ MUÑOZ M. A. (1995), Mujeres, espacio y sociedad. Hacia una geografía del género, Madrid, Editorial Síntesis.

SANTOS X. M. (2002), “Espacios disidentes en los procesos de ordenación territorial”, Documents d'Anàlisi Geogràfica, 40, pp. 69-104.

SERRA A. (2003), Les transformacions urbanístiques del barri del Mercadal de Girona: Una lectura des de la geografia del gènere, Memoria de investigación, Universitat de Girona.

SOLSONA M. (1989), “El problema de la medición del trabajo de la mujer”, Documents d'Anàlisi Geogràfica, 14, pp. 149-169.

\section{NOTES}

1. At the national level, Ministerio de Educación y Ciencia and Instituto de la Mujer (both at Madrid) and, at the regional level, Instituto Andaluz de la Mujer and Institut Català de les Dones.

2. European Science Foundation, European Commission (Directorate-General for Employment, Unit V/ D 5), Cost Program Action12. European Union funds also supported an international teaching collaboration for 8 years in gender and geography that brought together faculty and students from the Autonomous University of Barcelona with those from the University of Amsterdam (The Netherlands), National Technical University (Greece), Roskilde University (Denmark) and Sheffield and Durham Universities in the UK. The 1993 and 1998 courses were held in Barcelona. Collaborative research involving faculty and students at the Autonomous University of Barcelona with scholars in France and Germany has been supported by the Volkswagen Foundation. 


\section{ABSTRACTS}

During the last two decades gender studies have advanced in Spanish geography, constituting a subfield of social and cultural geography. They have incorporated the international perspectives that understand gender as a construction which challenges the artificial boundaries between the social, the cultural and the economic. On the one hand, Spanish gender geography drew early inspiration from the British and American work but, on the other, it has sustained the Spanish tradition of being more applied than theoretical. In this article, we will deal first with the institutional aspects linked to gender and power within the discipline in Spain; then we will deal with three topics that have been relevant in Spanish gender geography: the study of rural spaces, research on urban spaces and studies in postcolonial geography.

Pendant les vingt dernières années, les études de genre se sont développées dans la géographie espagnole, constituant une sous-section de la géographie sociale et culturelle. Elles ont inclus les perspectives internationales qui considèrent le genre comme une construction qui questionne les barrières artificielles entre le social, le culturel et l'économique. La géographie espagnole du genre s'est initialement inspirée des travaux britanniques et américains mais elle a également suivi la tradition espagnole qui prône la mise en application plus que la théorie. Cet article s'occupe d'abord des aspects institutionnels qui ont un rapport avec genre et pouvoir dans la discipline en Espagne ; ensuite, on examine trois sujets qui ont été importants dans la géographie du genre en Espagne : l'étude des espaces ruraux, la recherche sur les espaces urbains et les travaux en géographie post-coloniale.

\section{INDEX}

Mots-clés: géographie académique espagnole, espaces ruraux, espaces urbains, géographie postcoloniale, méthodes qualitatives

Keywords: Spanish academic geography, rural spaces, urban spaces, postcolonial geography, qualitative methods

\section{AUTHORS}

\section{FABIA DIAZ CORTÉS}

Departament de Geografia, Universitat Autònoma de Barcelona, Bellaterra (Spain), fabia.diaz@uab.cat

\section{MARIA DOLORS GARCIA RAMON}

Departament de Geografia, Universitat Autònoma de Barcelona, Bellaterra (Spain), mariadolors.garcia.ramon@uab.cat

\section{ANNA ORTIZ}

Departament de Geografia, Universitat Autònoma de Barcelona, Bellaterra (Spain), anna.ortiz@uab.cat 